\title{
4. The Political Roles of the Fiji Military: A Brief History of the Chiefs' Warriors, Heroes of the World Wars, Peacekeepers and Dictators
}

\author{
Hélène Goiran
}

Les Rôles Politiques des Militaires Fidjiens: brève histoire des Guerriers des Chefs, des Héros des Guerres Mondiales, des Soldats de la Paix et des Dictateurs

L'histoire militaire des Fidji a commencé en même temps que leur Histoire. La société précoloniale était largement fondée sur la guerre et l'art de la faire. L'administration britannique et les missions chrétiennes ont fait cesser les conflits armés mais les Fidjiens, héritiers d'une puissante tradition guerrière, ont cherché à la maintenir. Ils l'ont adaptée et l'ont utilisée pour rétablir puis pour consolider leur pouvoir politique ; d'abord dans le cadre de la colonisation, puis pour préparer l'indépendance et donner à leur pays souverain une place significative sur la scène internationale en participant avec succès à de nombreuses opérations de paix. C'est dans ce cadre qu'ils se sont engagés dans les deux Guerres mondiales, puis dans la Campagne de Malaisie. Depuis 1978, des milliers de soldats fidjiens ont été et sont déployés en permanence sur des théâtres d'opérations extérieurs (Liban, Sinaï, Bosnie, etc.) s'illustrant par leur courage et leur efficacité. Aujourd'hui encore, du fait de leur valeur, et, malgré le coup d'Etat du 5 décembre 2006 et les sanctions internationales décidées contre le gouvernement, l'ONU confie aux militaires fidjiens la protection de ses représentants et de ses installations en Irak. L'armée fidjienne occupe une place prépondérante dans la société et joue un rôle politique majeur, jusqu'à prendre le pouvoir par la force, dans les seuls coups d'Etat militaires de l'Océanie. Ce rôle politique a, sur le plan intérieur, complètement changé d'orientation en une vingtaine d'années. En 1987, les Royal Fiji Military Forces, avec le colonel Rabuka, déclaraient vouloir protéger les intérêts des Mélanésiens menacés par les Indo-Fidjiens. Depuis 2006, les Republic of Fiji Military Forces, solidaires du Commodore Bainimarama, se présentent comme les promoteurs d'un futur Etat multiracial et démocratique, dans lequel chaque citoyen, quelle que soit son origine ethnique, aura les mêmes 
Politics, Development and Security in Oceania

droits et devoirs. Pourtant, l'armée demeure presque exclusivement constituée de Fidjiens mélanésiens, et les Indo-Fidjiens n'y ont jamais eu leur place.

\section{The Chiefs' Warriors}

The military history of Fiji is as ancient as her History. In pre-colonial times, the warriors were the necessary implements of the chiefly power. The Chiefs gained or held authority and influence through the victories of their fighters. War was the natural occupation of men, who were all supposed to fight to protect the community. Some of them were dedicated fighters. Warfare training was a main part of young males' formation. The importance of the social role of the warriors was such that, like the nobles, they were buried with their wives. Moreover, the gods wanted human sacrifice and the vanquished were the usual victims. War and worship were intertwined. Without wars, the offerings could diminish, angering the gods, who could provoke disasters, therefore weakening the power of the chiefs. Frequent wars opposed those who aspired to nobility titles, extended territories, and superior prestige. All men being supposed to the chief's police, thousands of armed men assaulted the enemy groups. But the confrontation was habitually short and the number of casualties was limited, because a symbolic victory was sufficient. Generally, these conflicts were aimed at establishing power, not at exterminating the opponent, who could have been previously an ally, or indeed become one in the future.

Warriors were therefore a major instrument for the chiefs to win and hold power. The leaders who were able to mobilise, train and lead their men into battle could dominate more people on wider zones. The first contacts and exchanges with Westerners introduced firearms and the engagement, in the service of some chiefs, of foreigners whose competences played a major part in the evolution of politics.

The club was the Fijian warrior's favourite weapon. He had his spears, from ten to fifteen feet long and often richly carved, efficient bows and arrows, and slings for throwing stones; but, although these had each its special use, none approached the club in popularity. Whether his tribe was at war or at peace, he was seldom without it, for until the latter half of last century no Fijian left the precincts of his house unarmed. Whenever he left his village, even to work in his garden, he carried his club on his shoulder; and should he meet a man in the path, the club remained in that position, at the alert, until on friendly recognition both men lowered their weapon in greeting (Derrick 1957). 
These weapons themselves could have a political role:

The Mace of the Fiji House of the Representatives is the former favourite war club that was used in battle by Ratu Seru Cakobau. It is made of a type of hardwood called 'gadi'. He gave it as a gift to Queen Victoria of Great Britain in 1874, when Fiji became part of the British Empire. He named the war club Ai Tutuvi Kuta i Radini Bau (The coverlet of the Queen of Bau).

The club is beautifully mounted and decorated with emblems of peace, embellished with small silver doves and olive branches.

The Mace of the Fiji Senate is another war club used by Ratu Seru Cakobau. It was acquired during fighting with the hill tribes in 1874 . It is a root stock club called na waka. (http://www.parliament.gov.fj/ about/about.aspx?id=hmacehr)

In addition to traditional arms, modern weapons and western strategy enabled certain groups to gain influence over others, and that in a context where it seems that, previously, no group dominated durably and significantly.

This is how, notably, Cakobau, chief of Bau Island and adjacent areas, gained such authority, in the middle of the nineteenth century, as to be considered by the Europeans as the main leader of the entire Fiji archipelago, that is the Tui Viti, the King of Fiji.

In the early 1870s, in Levuka, the Western settlers constituted a government around Cakobau, This Cabinet, and its leader, protected themselves against those who challenged their legitimacy with a 'Royal Army'. This force comprised 1,000 men, organised, trained and used in the western way. It was commanded by a British Officer who had served in the Crimea and in India.

On the cession to the Crown, in 1874, London took over control of the 'Royal Army', and in 1876, the colonial administration renamed it the Armed Native Constabulary but retained its military organisation. The colonial authorities employed the ANC for the 'pacification' of tribes resisting the British presence.

During the same period, the Missions, whose influence had been growing rapidly since the conversion of Cakobau, in 1854, prohibited traditional warfare. Apart from those of the rebellious tribes, the warriors found a new mission by joining the Constabulary or the Police. The ANC was terminated in 1905, having no mission after the 'pacification' and unification of the Fiji Islands under British authority. 
Politics, Development and Security in Oceania

\section{The First World War}

In 1914, in Fiji, the British settlers and many natives desired to participate in the combat in Europe. For the Fijians, who were now the subjects of the Crown, the engagement was obvious: not to fight for the Queen would have been a shameful and unforgivable breach of the traditions. The Police and all defence-related associations, such as the riflemen, were mobilised, and a Fiji Defence Force was formed.

Approximately seven hundred men of European descent left Fiji for active service with the Allies.

Natives also were eager to join the front, but the British Command refused these coloured men. A few young chiefs, who were studying overseas at the time, succeeded in joining the Maori units.

The famous Ratu Sukuna, rejected because of his race by the British War Office, enlisted in the French Foreign Legion. Seriously wounded in action and highly decorated, he was sent back to Suva as a hero. There, he succeeded in convincing the colonial authority to send a Labour Detachment of about one hundred Fijians to Europe in May 1917.

The Indians in Fiji, at that time, were still indentured labourers. In 1916, their leaders tried to convince the colonial authorities to constitute an Indian platoon. The 32 volunteers were ignored by the government.

\section{The Second World War}

After the First World War, in the 1920s, the Defence Force, still composed of indigenous Fijians commanded by Western Officers, was used against striking Indian workers, so creating a feeling of alliance between the Fijians and Europeans against the Indians.

However, the Indian Platoon was at last created within the Fiji Defence Force in 1934 as part of policy of giving Indo-Fijians greater recognition and opportunity to participate in the general life of the Colony.

The platoon was disbanded in 1940. The reason given for this action during a war was shortage of equipment: The real reason was that members of the platoon had asked for equal pay with the Europeans. The New Zealand military authorities (who commanded the Fiji Army at the start of the War) feared that this dissatisfaction could spread to the ethnic Fijians. 
When the Second World War began, the Colony already had a Fiji Defence Force. A general mobilisation was ordered. Like twenty years before, the British authorities did not want the natives to be sent to the front.

However, the jungle skills of Fijian soldiers were notable after a special party of Fiji Commandos was sent to the Solomon Islands for guerrilla operations in support of the Allied Forces in operation there. The party numbered 30 men under the command of Captain D. Williams. They became the first Fijians to go into action in the World War Two. The First Battalion, Fiji Infantry Regiment (1FIR) was assigned to the Island of Bougainville in December 1943. This followed the establishment of a beachhead in Empress Augusta Bay by the United State Marines. The battalion's job on the island was to be forward scouts in support of the United States. The excellent results achieved by the First Battalion, Fiji Infantry Regiment led to a decision to send the Third Battalion, Fiji Infantry Regiment (3FIR) to join the First Battalion in operation in Bougainville. It was in Bougainville that Corporal Sefanaia Sukanaivalu of the Third Battalion, Fiji Infantry Regiment, was posthumously awarded the Victory Cross in June 23, 1944 when a larger and well-concealed enemy force ambushed his platoon. The First Commandos, Fiji Guerrillas went into action on the island of New Georgia in 1943 and were tasked to locate a party of enemy soldiers occupying the island. During this operation the Fijian soldiers suffered their first death in action when Lieutenant B. Masefield was killed after a patrol he was leading was caught in an enemy artillery barrage. The First Commandos were late replaced by the Second Commandos, Fiji Guerrillas on November 25, 1943 (RFMF Website).

Politically and socially, the participation in the Solomon Campaign was of major significance for the Fijian soldiers, who operated with Westerners on the same level. They constituted a consistent group notwithstanding their different origins and were unanimously recognised as valuable servicemen. As a consequence, the Fiji Defence Force was not completely dismantled after the war. Moreover, in 1949, it was officially decided that the Fiji Defence Force would be supported by New Zealand.

\section{The Malayan Campaign}

The impression that the Fijian soldiers had left was enduring: in 1951, London wished to deploy a Fiji Battalion in the Malayan Campaign.

World War Two veterans constituted the core of this Fiji Battalion. These men spent four years in the jungle to 'hunt and kill'. The appreciation of the value of 
the Fijian servicemen as commandos was even superior to those in the Solomon Campaign: in Malaya, the officers were Fijian; London left the Fijians to chose the method of operating, which was shocking. In this war, contact with the enemy was direct; combat close, the environment dreadful. The Fijians were particularly well adapted, and their longstanding warrior tradition led them to the destroy the enemy without hesitation.

Possibly, for some Fijians, the presence of Chinese communists in Malaya could be compared to the presence of Indians in Fiji: unwelcome visitors who had to be chased out. This may explain the enthusiasm of the members of the 'Fiji Batt' to carry out their mission.

During the Malayan Campaign, as well as during the two World Wars, the Fijian units were organised according to the customary hierarchy. The colonial authorities encouraged this structure, which guaranteed loyalty and dedication. Through their commitment, as individuals, the Fijian servicemen gained prestige among their peers. As a community, following their successful overseas engagement, the Fijians gained cohesiveness, in opposition to the Indo-Fijians, who scarcely participated in the wars.

\section{The Defence Force of Sovereign Fiji}

After the Malayan Campaign, at the time of the preparation of Fiji's independence, London tried, to no avail, to convince the Fijian representatives that the future State only needed a police force, not an army. Although the Fijians had been impressive combatants, or rather because they had, the British authorities did not want to maintain a significant defence force in Fiji, fearing for the internal security and the safety of the Indian part of the population: the Indians had then become more numerous than the indigenous Fijians.

In 1970, the new sovereign State inherited what remained of the Fiji Defence Force, turned into the Royal Fiji Military Forces, still almost exclusively composed of indigenous Fijians. The first years of independence saw the formation of a Fijian senior staff in the RFMF. Their main mission was to guarantee internal security, by assisting, should it be necessary, the police in maintaining or restoring law and order in accordance with Government decisions. The RFMF also participated in rural development and youth formation mostly in favour of the Fijians.

The command of the RFMF was close to the government. Together, they decided to provide this small army with international experience by appointing it to peacekeeping missions. Without doubt, it was also a long-thinking reflexion that led to the employment of the Fijians' warriors skills as a powerful instrument of international politics for the young Fiji State. 
From 1978, a battalion was engaged in the United Nations Force in Lebanon (UNIFIL). From 1982, a second battalion was engaged in the multinational peacekeeping force in Sinai (MFO), under United States command.

Other similar commitments followed, in Zimbabwe-Rhodesia, Sinai, Afghanistan and Pakistan, Iraq and Kuwait, Somalia, Bougainville, East Timor, Solomon Islands. Some of them are still ongoing. So, for more than thirty years, more than 1,000 Fijian men were deployed at the same time in external theatres. Nearly all of them were, and still are, indigenous Fijians.

In total, about 15,000 Fiji men have served in these external operations. This toughened them up, brought their families and the country a substantial income, providing Fiji with international recognition and appreciation, thanks to their professionalism, operational value, bravery and strength. Therefore, until the mid-1980s, a military coup d'état in Fiji was thought to be very unlikely. The submission of the RFMF to the government, the strength of democracy in Fiji, and the multiracial harmony commonly received international acknowledgement and approval. In 1986, Pope John Paul described the country as 'the way the world should be'.

\section{The Indo-Fijians and the Defence Force}

Since its establishment, the Fijian military forces have been strong supporters of the long-established customary leaders and the Methodist church. Very early, too, a clear separation (segregation) had been established between the indigenous Fijians and the Indian migrants. The Military Force (whatever its name at the time) was employed to counter their social claim movements.

The RFMF's ceremonial traditions are very Fijian and Christian (yaqona sessions, frequent prayers, etc). There is really no incentive for the Indians to enlist. Their very small number in the RFMF is a consequence of their ethnic identification, religions, interests and aspirations, as well as an outcome of the place accorded to them in Fijian society from the time of the arrival of their ancestors, due to the British colonial authorities, more than one hundred years ago.

Those few Indo-Fijians who join the RFMF, however, have a strong perseverance and motivation.

Some hold important posts as lawyers, doctors or aides-de-camp; and some are part of the higher command and close to the Commander of the Republic of Fiji Military Forces. Colonel Mohammed Aziz, for example, Bainimarama's deputy, has been in command several times during the recent past, while the Commodore was abroad. 
Politics, Development and Security in Oceania

A brief history of the Indo-Fijian peoples is important to this narrative. Today, the Republic of the Fiji Islands has a population of 830,000. Nearly 40 per cent of them are Indo-Fijians, mostly born in Fiji to parents themselves born there, and they do not have any connection with India anymore, despite a strong Indian culture.

Their ancestors arrived several generations ago. The movement has been massive: between 1879 and 1916, more than 60,000 Indian indentured labourers, including women and children were transported to Fiji. Many settled there. The 1921 census showed 84,000 Fijians and 60,000 Indians (there were also 12,000 Europeans, Chinese, Rotumans and others).

Nevertheless, they are still called Indians, both commonly and officially, in order to differentiate them from the Indigenous Fijians and the citizens of other origins. The Constitution so establishes four separate electoral rolls, according to the voters' registration as Fijians; Indians; Rotumans; or others.

There are few inter-community marriages, and a small number of Fiji citizens have Fijian and Indian mixed blood. Those who have, belong to one of the communities or to the other, neither to both nor to a real new one of half-caste. This situation is a heritage of the colonial times. The conditions of Independence, in 1970, set up this separation, and therefore the subsequent identification of each Fiji Islander.

Apart from historical and colonial legacy, many characteristics separate the communities, such as religion (the Fijians being Christians and the Indians being Hindus or Muslims), and profession (three quarters of the farmers are Indians, but eighty-three per cent of the land is Fijian-owned).

Until 1987, and the first coup d'état, identities in Fiji seemed plain and clear for everyone. The different communities lived alongside each other without real integration or worrying tension, in what appeared to be a peaceful and prosperous multiethnic and democratic country. The travel agencies successfully sold trips to 'Paradise'.

Nonetheless, the compartmentalised country was built on an unsound foundation, organised by a raced-based Constitution that did not create a common national identity. 'Indigenous Fijians were instilled with fear of dominance and dispossession by Indo-Fijians, and they desired protection of their status as the indigenous people. Indo-Fijians, on the other hand, felt alienated and marginalised, as second class citizens in their own country, the country of their birth' (Bainimarama 2007). And then took place the first military coup d'état to occur in the Pacific. 


\section{7: Colonel Rabuka's Ethno-nationalist Coup d'Etat}

In 1987, the general elections saw the defeat of the customary establishment and resulted in the formation, for the first time, of a truly multiracial government under the leadership of Labour's Dr Timothy Bavadra.

In May 1987, Lieutenant Colonel Sitiveni Rabuka, number three in the RFMF hierarchy, and descendant of customary warriors, overthrew the government. His operation was carefully planned and prepared, the RFMF followed him. He declared to have taken action in order to preserve the interest of the Fijians against the Indians. This was the first military coup of the history of Fiji and Oceania. A second one occurred soon after: in September of the same year, Sitiveni Rabuka ousted the government again and declared Fiji a Republic. In 1990 a new constitution was endorsed, establishing the Fijian prominence. Mr Rabuka was made a life member (the only one ever!) of the Great Council of Chiefs, although a commoner, due to the fact that he had carried out his military coup in 1987 in the name of indigenous rights.

For years, the Rabuka government placed Army officers in many posts of responsibilities. The RFMF; henceforth Republic of Fiji Military Forces, greatly grew in strength, equipment, and budget. As a member of a customary warrior clan and a peacekeeping operations hero, Sitiveni Rabuka had charisma and authority in Fiji. He retained political power for more than ten years during which, despite strong international reproof against his regime, Fijian Peacekeepers remained appreciated and welcome in the United Nations' missions.

In 1997, still in power, Sitiveni Rabuka instigated the adoption of a new Constitution, supposed to be considered as progressive. Its provisions maintained some of the Fijians' advantages, but the Indians had significant rights. In 1999, the Labour party won the general elections and its leader, Mahendra Chaudhry, became Prime Minister. Even more than in 1987, access of the Indo-Fijians to political power was a reality. The Melanesian nationalists could not bear it.

\section{0: The RFMF's Reaction to the Speight Coup d'Etat}

In May 2000, George Speight, a half-European businessman, leading an action with members of the Special Forces, took Fiji's Parliament hostage for 56 days. The support of the RFMF was expected, but its Commander, Commodore Bainimarama, backed by the large majority of his men, opposed the coup. 
Politics, Development and Security in Oceania

Bainimarama declared martial law, negotiated with the putschists, succeeded in having the hostages released and the weapons returned. Moreover, he had the rebels arrested, and, after only a few weeks gave the power back to civilians. A provisional government was installed, led by Laisenia Qarase. Commodore Bainimarama and his supporters intended to see all the instigators of the coup uncovered and punished. But Qarase and his followers revealed themselves to be in favour of 'Melanesian prominence'. They were maintained in power by the general elections of 2001 and 2006. Despite its racist policies, the Qarase governments were also approved by the international community.

Commodore Bainimarama also stayed in place as Commander RFMF. He too had many supporters, including the President. For years he opposed Qarase and his policy. Despite visible tensions and dissensions within the RFMF, the 'Commodore' remained their legitimate and rightful commander. Steadily, he opposed the government. With him, therefore, the servicemen did the same, refuting what the Commodore and his supporters saw as non-democratic policy. They demanded the abandonment of outdated and unfair provisions that favoured ethnic Fijians and disadvantaged the Indo-Fijian half of the country's population notwithstanding their hundred-year old presence in Fiji.

\section{Since 5 December 2006: the Anti-ethno- nationalist Bainimarama's Coup}

On 5 December 2006, through a bloodless coup, Commodore Bainimarama removed the Qarase government. He dissolved the Parliament and, after a few weeks, assumed the title and responsibilities of Prime Minister. He announced and launched anti-corruption campaigns and non-racial government. He admits to having conducted a coup d'état and declared so in front of the United Nations General Assembly. He pledged to organise truly democratic elections for early 2009.

For much of the post-Independence period, the Military Forces in Fiji had been strong supporters of the long-established customary leaders, including by conducting the two coups of 1987 to protect the traditional Melanesian interest. From 2000, under Commodore Bainimarama, the Army completely changed its position, claiming to champion equal rights for all the citizens, contesting the archaic customary power.

Either by supporting or opposing by force the customary chiefs, the elected governments or the putschists, Fijian soldiers have played a major political role. The 'Commodore', without doubt is a military commander who conducted a coup d'état to overthrow a functioning democracy. He has assumed dictatorial 
power. But my point is that in the historical, social and political context of Fiji, the positions and actions of the 'Commodore' and the RFMF could be said to have historical coherence.

By assuming political and administrative authority they perpetuate, in their own different ways, the ancient role of the pre-colonial warriors. And recent history seems to indicate that there can be a future for Fijian Dictators: after he had lost power in 1999, Brigadier Rabuka did not disappear from the political scene. Quite the opposite: nobody really accused him of having definitively destroyed the peaceful and prosperous Fiji of the 1980s. Neither the local population nor the international community turned their back on him. Not being Prime minister anymore, because he had led the indigenous Fijian government to a severe defeat and paving the way for the country's first Prime minister of ethnic Indian origin, trade unionist Mahendra Chaudhry. Following the polls, Rabuka was elected as chairman of the Great Council of Chiefs. Soon Rabuka resigned from the chairmanship of the Great Council and membership of the Parliament because he had taken up a Commonwealth mission, as the Secretary-General's Special Envoy to Solomon Islands. What better international recognition could he have wished for?

Later, allegations were made against him by former President Ratu Sir Kamisese Mara of complicity in the Fiji coup of 2000. Rabuka was also accused of instigating or supporting the mutiny that took place at Suva's Queen Elizabeth Barracks on 2 November 2000. He was judged 'not guilty'.

\section{References}

Bainimarama, V. 2007. Speech to United Nations, cited 'Fiji: Interim PM outlines plans for referendum', Radio Australia (2 October)

Derrick, R. 1957. 'Notes on a Fijian club with a system of classification'. Journal of the Polynesian Society. 66(4): 391-395. 